\title{
PEMANFAATAN LAGU SECARA KOMERSIAL PADA RESTORAN SERTA KEBERADAAN PENGUNJUNG YANG MENYANYIKAN LAGU SECARA VOLUNTEER
}

\author{
Oleh: \\ Komang Ardika* \\ Marwanto** \\ Bagian Hukum Bisnis Fakultas Hukum Universitas Udayana
}

\begin{abstract}
Abstrak
Lagu adalah salah satu karya cipta yang dilindungi oleh Undang-Undang Republik Indonesia Nomor 28 Tahun 2014 Tentang Hak Cipta. Pencipta lagu memiliki hak eksklusif yang terdiri dari hak ekonomi dan hak moral. Pihak lain tidak dapat memanfaatkan hak ekonomi lagu tanpa izin dari pencipta lagu. Salah satu bentuk pemanfaatan lagu adalah melakukan pertunjukan lagu di restoran yang menyediakan alat musik. Permasalahan yang diangkat dalam penelitian ini adalah keberadaan pengunjung restoran yang menyanyikan lagu milik orang lain secara suka rela. Metode penelitian yang digunakan adalah penelitian hukum normatif dengan pendekatan peraturan perundang-undangan dan konseptual. Hasil penelitian menunjukan keberadaan pengunjung restoran yang menyanyikan lagu milik orang lain termasuk dalam kategori penggunaan secara komersial dalam hal pihak restoran mendapatkan manfaat ekonomi atau mendapatkan manfaat yang dapat mempengaruhi nilai uang dengan keberadaan pengunjung restoran yang membawakan karya cipta lagu milik orang lain.
\end{abstract}

Kata Kunci: lagu, manfaat ekonomi, penggunaan secara komersial

\begin{abstract}
Song is one of the copyrighted works protected by the Republic of Indonesia Law Number 28 of 2014 concerning Copyright. Songwriters have exclusive rights consisting of economic rights and moral rights. Other parties cannot take advantage of the song's economic rights without permission from the songwriter. One form of utilizing songs is performing songs in restaurants that provide

* Komang Ardika adalah Mahasiswa Fakultas Hukum Universitas Udayana, ardikakomang97@gmail.com

** Dr. Marwanto, S.H., M.Hum. adalah Dosen Fakultas Hukum Universitas Udayana, marwanto@unud.ac.id
\end{abstract}


musical instruments. The problem raised in this research is the presence of restaurant visitors who sing songs of other people voluntarily. The research method used is normative legal research with a legal and conceptual approach. The results showed that the presence of restaurant visitors singing other people's songs was included in the category of commercial use in the event that the restaurant gets economic benefits or gets benefits that can affect the value of money with the presence of restaurant visitors who bring other people's songs.

Keywords: songs, economic benefits, commercial use 


\section{PENDAHULUAN}

\subsection{Latar Belakang}

Manusia diciptakan oleh Tuhan Yang Maha Esa dengan akal budi. Akal budi manusia mampu berpikir kreatif kemudian menciptakan ilmu pengetahuan, seni dan teknologi.2 Perkembangan karya manusia lahir dari proses yang panjang dan pengorbanan yang besar yang melahirkan suatu hak yaitu hak cipta (copy right). Ciptaan adalah setiap hasil karya cipta seseorang atau beberapa orang yang secara sendiri-sendiri atau bersama-sama menghasilkan suatu ciptaan yang bersifat khas dan pribadi. Karya cipta dihasilkan atas inspirasi, kemampuan, pikiran, imajinasi, kecekatan, keterampilan, atau keahlian yang diekspresikan oleh pencipta dalam bentuk nyata. Bentuk nyata hasil ekspresi pencipta terwujud dalam bidang ilmu pengetahuan, seni, dan sastra.

Hukum hak cipta Indonesia memberikan perlindungan pada pencipta berupa ha katas karyanya setelah dibuat dalam bentuk karya nyata (fiksasi) bukan dalam bentuk ide. ${ }^{3}$ Terhadap hasil pemikiran yang telah diekspresikan dalam bentuk nyata, pencipta mendapat perlindungan secara otomatis tanpa mengurangi pembatasan sesuai dengan ketentuan peraturan perundang-undangan. Perlindungan yang dimiliki oleh pencipta berupa kepemilikan hak eksklusif terhadap ciptaannya. Hak eksklusif adalah hak yang dimiliki oleh pencipta saja, pihak lain tidak dapat memanfaatkan hak ekslusif tanpa izin dari pencipta.

2 M. Syamsudin, 2001, Nilai-Nilai Karya Cipta Dan Problematik Perlindungan Hukumnya : Jurnal Hukum Ius Quia Iustum Vol. 8 Nomor 16, Universitas Islam Indonesia

${ }^{3}$ Ni Ketut Supasti Dharmawan, 2017, Protecting Traditional Balinese Weaving Trough Copyright Law : Is It Appropriate? : Jurnal Diponegoro Law Review Vol. 02 Nomor 01, Universitas Diponegoro 
Salah satu ciptaan yang dilindungi berdasarkan Pasal 40 ayat (1) huruf d Undang-Undang Republik Indonesia Nomor 28 Tahun 2014 Tentang Hak Cipta adalah lagu. Lagu berdasarkan Kamus Besar Bahas Indonesia adalah ragam suara yang berirama. Lagu adalah bentuk seni dari manusia yang berkembang melalui budaya sebagai identitas diri. Lagu adalah salah satu unsur musik berbentuk komposisi yang mengungkapkan perasaan dan pikiran penciptanya. ${ }^{4}$

Pencipta lagu memiliki hak eksklusif berupa hak ekonomi dan hak moral terhadap lagu yang diciptakannya. Hak eksklusif berarti hanya pencipta lagu saja yang dapat mengambil manfaat moral maupun manfaat ekonomi. Pihak lain tidak dapat memanfaatkan hak ekslusif karya cipta lagu secara komersial tanpa izin dari pencipta. Penggunaan secara komersial adalah pemanfaatan ciptaan dan/atau produk hak terkait dengan tujuan untuk memperoleh keuntungan ekonomi dari berbagai sumber atau berbayar.

Salah satu bentuk pemanfaatan hak cipta lagu yang dilarang tanpa izin pencipta adalah melakukan pertunjukan atas karya cipta lagu. Pemanfatan ciptaan lagu dapat dilakukan oleh siapa saja yang dan dimana saja. Tempat yang sering menjadi pertunjukan lagu adalah sebuah restoran yang menyediakan fasilitas live music. Live music adalah salah satu daya pikat sebuah restoran dalam menarik pengunjung. Selain menikmati makanan dan minuman, pengunjung dapat menikmati lagu-lagu populer.

Permasalahan muncul saat terdapat pengunjung restoran yang hendak menyumbangkan lagu secara suka rela di restoran. Pertunjukan karya cipta lagu oleh pengunjung restoran yang bukan pencipta lagu secara suka rela dan restoran yang tidak

4 Jamalus, 1988, Pengajaran Musik Melalui Pengalaman Musik, Departemen Pendidikan Dan Kebudayaan, Jakarta, h. 1. 
memiliki izin tertulis dari pencipta lagu untuk melaksanakan pertunjukan lagu apakah dapat dikategorikan sebagai penggunaan secara komersial.

Berdasarkan hal tersebut, penulis tertarik untuk mengangkat dalam karya ilmiah ini dengan judul "Pemanfaatan Lagu Secara Komersial Pada Restoran Serta Keberadaan Pengunjung Yang Menyanyikan Lagu Secara Volunteer".

\subsection{Rumusan Masalah}

Adapun permasalahan yang diangkat adalah apakah keberadaan pengunjung restoran yang menyanyikan lagu secara volunteer dapat dikategorikan sebagai penggunaan secara komersial oleh pihak restoran.

\subsection{Tujuan Penelitian}

Berdasarkan rumusan masalah diatas tujuan yang ingin dicapai dalam penelitian ini adalah untuk mengetahui keberadaan pengunjung restoran yang menyanyikan lagu secara volunteer dapat dikategorikan sebagai penggunaan secara komersial oleh pihak restoran.

II. ISI

\subsection{Metode Penelitian}

Metode penelitian yang digunakan dalam penelitian ini adalah metode penelitian hukum normatif. Jenis pendekatan yang digunakan adalah pendekatan peraturan perundang-undangan dan konseptual.

\subsection{Hasil dan Analisis}

Penggunaan secara komersial sebagaimana diatur dalam Pasal 1 angka 24 Undang-Undang Republik Indonesia Nomor 28 Tahun 2014 Tentang Hak Cipta adalah pemanfaatan ciptaan dan/atau produk hak terkait dengan tujuan untuk memperoleh 
keuntungan ekonomi dari berbagai sumber atau berbayar. Dalam ketentuan tersebut dapat ditarik unsur-unsur yang menggambarkan penggunaan secara komersial yaitu:

a) pemanfaatan ciptaan dan/atau produk hak terkait; dan

b) memperoleh keuntungan ekonomi;

Ciptaan sebagaimana diatur dalam Pasal 1 angka 3 Undang-Undang Republik Indonesia Nomor 28 Tahun 2014 Tentang Hak Cipta yaitu segala hasil karya dalam bidang ilmu pengetahuan, seni, dan sastra yang dihasilkan atas inspirasi, kemampuan, pikiran, imajinasi, kecekatan, keterampilan, atau keahlian yang diekspresikan dalam bentuk nyata. Ciptaan adalah segala hal yang awalnya hanya berada dalam pikiran seseorang kemudian diolah sehingga memiliki wujud nyata yang dapat ditangkap oleh panca indra manusia. Lagu adalah salah satu jenis karya cipta dalam bidang seni.

Hak cipta berdasarkan Pasal 1 angka 1 Undang-Undang Republik Indonesia Nomor 28 Tahun 2014 Tentang Hak Cipta adalah hak eksklusif pencipta yang timbul secara otomatis berdasarkan prinsip deklaratif setelah suatu ciptaan diwujudkan dalam bentuk nyata tanpa mengurangi pembatasan sesuai ketentuan peraturan perundang-undangan. Terhadap sebuah ide dalam membuat lagu yang telah diwujudkan dalam bentuk nyata sehingga dapat didengarkan oleh orang lain mendapat perlindungan hukum secara langsung tanpa ada pendaftaran terlebih dahulu. Sistem perlindungan tersebut bernama sistem perlindungan secara otomatis (automatically protection). Sistem perlindungan secara otomatis adalah perlindungan hukum terhadap hasil karya cipta diperoleh secara otomatis oleh pencipta tanpa ada proses pendaftaran terlebih dahulu. Perlindungan mulai 
diberikan sejak karya ciptanya sudah diwujudkan dalam bentuk karya cipta nyata (expression work). ${ }^{5}$ Pengertian diwujudkan mengandung makna dapat dibaca, didengar, atau dilihat sesuai dengan bentuk ciptaan. Wujud perlindungan tersebut berupa kepemilikan hak cipta bagi pencipta.

Pencipta adalah seorang atau beberapa orang yang secara sendiri-sendiri atau bersama-sama menghasilkan suatu ciptaan yang bersifat khas dan pribadi. Penentuan siapa pencipta yang menghasilkan ciptaan adalah orang yang namanya disebut dalam ciptaan, dinyatakan sebagai pencipta pada suatu ciptaan, disebutkan dalam surat pencatatan ciptaan, dan/atau tercantum dalam daftar umum ciptaan sebagai pencipta. Ciptaan yang terdiri atas beberapa bagian tersendiri yang diciptakan oleh dua orang atau lebih yang dianggap sebagai pencipta adalah orang yang memimpin dan mengawasi penyelesaian seluruh ciptaan, namun jika orang yang memimpin dan mengawasi penyelesaian seluruh ciptaan tidak ada maka yang dianggap sebagai pencipta adalah orang yang menghimpun ciptaan dengan tidak mengurangi hak cipta masing-masing atas bagian ciptaannya. Ciptaan yang dirancang oleh seseorang kemudian diwujudkan serta dikerjakan oleh orang lain di bawah pimpinan dan pengawasan perancang, yang dianggap sebagai pencipta yaitu orang orang yang merancang ciptaan.

Pencipta lagu memiliki hak ekslusif yang terdiri dari hak moral dan hak ekonomi. Hak moral adalah hak yang harus tetap dilekatkan secara abadi pada hasil ciptaan yang dilahirkan oleh pencipta lagu. Secara umum hak moral dibagi menjadi dua, yaitu hak untuk diakui sebagai pencipta lagu (authorship right atau paternity right) dan hak keutuhan karya (the right to protect the

$5 \mathrm{Ni}$ Ketut Supasti Dharmawan, dkk., 2018, Harmonisasi Hukum Kekayaan Intelektual Indonesia, Swasta Nulus, Denpasar, H. 20 
integrity of the work). ${ }^{6}$ Hak moral pencipta lagu melekat secara abadi. Hak moral terdiri dari lima jenis hak yaitu:

a) hak untuk tetap dicantumkan atau tidak dicantumkan namanya pada salinan sehubungan dengan pemakaian ciptaannya untuk umum;

b) hak untuk menggunakan nama alias atau samarannya;

c) hak untuk mengubah ciptaannya sesuai dengan kepatutan dalam masyarakat;

d) hak untuk mengubah judul dan anak judul ciptaan; dan

e) hak untuk mempertahankan haknya dalam hal terjadi distorsi ciptaan, mutilasi ciptaan, modifikasi ciptaan, atau hal yang bersifat merugikan kehormatan diri atau reputasinya. ${ }^{7}$

Selama pencipta lagu masih hidup, hak moral tidak dapat dialihkan namun pelaksanaanya dapat dialihkan dengan wasiat atau sebab lain sesuai dengan ketentuan peraturan perundangundangan setelah pencipta lagu meninggal dunia. Pengalihan pelaksanaan hak moral dapat diterima atau ditolak oleh penerima hak dengan syarat dinyatakan secara tertulis.

Hak ekonomi adalah hak yang memberi manfaat ekonomi kepada pencipta. ${ }^{8}$ Hak ekonomi terdapat pembatasan masa menikmati manfaat ekonomi ciptaan. Bila batas waktu berakhir maka kekuatan monopoli juga berakhir. Status ciptaan yang telah

${ }^{6}$ Khoirul Hidayah, 2017, Hukum Hak Kekayaan Intelektual, Setara Press, Jawa Timur, H. 40.

7 Distorsi ciptaan adalah tindakan pemutarbalikan suatu fakta atau identitas ciptaan. Mutilasi ciptaan adalah proses atau tindakan menghilangkan sebagian ciptaan. Modifikasi ciptaan adalah pengubahan atas ciptaan.

8 OK Saidin, 2015, Aspek Hukum Hak Kekayaan Intelektual (Intellectual Property Rights), Cetakan ke-9, PT Raja Grafindo Persada, Jakarta, H. 222. 
berakhir hak ekonominya akan menjadi public domain. Karya ciptaan yang telah menjadi public domain berarti karya ciptaan tersebut bisa dieksploitasi oleh masyarakat umum tanpa memerlukan ijin apapun. ${ }^{9}$ Hak ekonomi dari ciptaan lagu berlaku selama hidup pencipta dan terus berlangsung selama 70 (tujuh puluh) tahun setelah pencipta lagu meninggal dunia. Hak ekonomi pencipta sebagaimana diatur dalam Pasal 40 Undang-Undang Republik Indonesia Nomor 28 Tahun 2014 Tentang Hak Cipta terdiri dari:

a) penerbitan ciptaan;

b) penggandaan ciptaan dalam segala bentuknya;

c) penerjemahan ciptaan;

d) pengadaplasian, pengaransemenan atau pentransformasian ciptaan;

e) pendistribusian ciptaan atau salinannya;

f) pertunjukan ciptaan;

g) pengumuman ciptaan;

h) komunikasi ciptaan; dan

i) penyewaan ciptaan.

Pihak lain yang bukan pencipta lagu wajib mendapatkan izin terlebih dahulu dari pencipta untuk melakukan hak-hak ekonomi tersebut. Pemanfaatan hak-hak ekonomi pencipta lagu dapat dilakukan tanpa izin terlebih dahulu kepada pencipta lagu dengan membayar imbalan kepada pencipta melalui lembaga manajemen kolektif dimana pencipta lagu terdaftar sebagai anggota. Lembaga manajemen kolektof adalah institusi yang berbentuk badan hukum nirlaba yang diberi kuasa oleh pencipta lagu guna mengelola hak-hak ekonominya dalam bentuk menghimpun dan mendistribusikan imbalan atas pemanfaatan

9 Henry Soelistyo, 2011, Hak Cipta Tanpa Hak Moral, Rajawali Pers, Jakarta, H. 51. 
hak-hak ekonomi. Pihak yang tidak mendapatkan izin dari pencipta atau membayar royalti dapat dimintakan ganti rugi pembayaran sejumlah uang yang dibebankan kepada pelaku pelanggaran hak ekonomi pencipta berdasarkan putusan pengadilan perkara perdata yang berkekuatan hukum tetap.

Hak cipta termasuk dalam sistem hukum benda sehingga hak cipta dapat pula dikatakan sebagai hak kebendaaan. Hak kebendaan terdiri dari hak kebendaan berwujud dan hak kebendaan tidak berwujud. Hak cipta termasuk dalam hak kebendaan yang tidak berwujud (immaterial) sebagaimana diatur dalam Pasal 16 ayat (1) Undang-Undang Republik Indonesia Nomor 28 Tahun 2014 Tentang Hak Cipta. Sebagai suatu benda maka hak cipta dapat menjadi objek milik sehingga dapat diperdagangkan, dialihkan kepada pihak lain, dan diwariskan. ${ }^{10}$ Pengalihan hak cipta dapat disebabkan karena pewarisan, hibah, wakaf, wasiat, perjanjian tertulis, atau sebab lain yang dibenarkan oleh peraturan perundang-undangan.

Hak kebendaan adalah hak yang memberikan kekuasaan langsung kepada seseorang yang berhak menguasai sesuatu benda dalam tangan siapa pun juga benda itu berada. Hubungan hukum antara seseorang dengan benda sering disebut dengan hukum kebendaan atau hukum harta kekayaan mutlak. Dalam hak kebendaan terdapat hak mutlak yang berlaku dan harus dihormati oleh setiap orang.

Hukum harta kekayaan mutlak adalah ketentuanketentuan yang mengatur tentang hak-hak kebendaan dan barang-barang tak berwujud. Hukum harta kekayaan menurut Titik Triwulan adalah peraturan-peraturan tentang hak dan kewajiban yang bernilai uang atau peraturan-peraturan yang

10 Abdulkadir Muhammad, 2014, Hukum Perdata Indonesia, PT Citra Aditya Bakti, Bandung, h. 128. 
mengatur hubungan hukum antara orang dengan benda atau sesuatu yang dapat dinilai dengan uang. ${ }^{11}$ Salim berpendapat bahwa hukum harta kekayaan adalah suatu ketentuan hukum yang mengatur tentang hubungan hukum yang menyangkut hak dan kewajiban yang memengaruhi nilai uang. ${ }^{12}$ Sehingga hak cipta sebagai hak kebendaan adalah hubungan hukum antara pencipta dengan ciptaannya (benda tidak berwujud) yang dapat dinilai dengan uang.

Pada hak cipta terdapat hak ekonomi yang dapat diartikan sebagai hak yang dapat memberi manfaat ekonomi (dapat dinilai dengan uang) kepada pencipta. Salah satu unsur dalam penggunaan secara komersial adalah memperoleh keuntungan ekonomi. Keuntungan ekonomi berdasarkan pemaparan mengenai hak cipta sebagai benda diatas dapat ditarik sebuah pengertian yaitu keuntungan yang dapat dinilai dengan uang atau keuntungan yang dapat mempengaruhi nilai uang.

Dengan mencermati penjabaran terkait unsur-unsur dari penggunaan secara komersial dalam Pasal 1 angka 24 UndangUndang Republik Indonesia Nomor 28 Tahun 2014 tentang Hak Cipta maka keberadaan pengunjung restoran yang menyanyikan lagu secara suka rela milik orang lain termasuk dalam melakukan pemanfaatan hak ekonomi pencipta lagu berupa melakukan pertunjukan atau menyanyikan lagu tersebut. Pengunjung restoran yang bernyanyi secara suka rela tidak mendapatkan manfaat ekonomi dalam bentuk apapun, sehingga tidak termasuk menggunakan secara komersial ciptaan orang lain.

11 Titik Triwulan Tutik, 2011, Hukum Perdata Dalam Sistem Hukum Nasional, Cetakan ke-3, Kencana, Jakarta, h. 141.

12 Salim HS, 2002, Pengantar Hukum Perdata Tertulis (BW), Sinar Grafika, Jakarta, h. $13-15$. 
Pihak restoran sebagai penyedia fasilitas peralatan live music tidak melakukan penggunaan secara komersial ciptaan jika tidak mendapatkan manfaat ekonomi dari keberadaan pengunjung restoran yang pada awalnya adalah kegiatan suka rela. Namun, jika pihak restoran secara nyata mendapatkan manfaat ekonomi atau mendapatkan manfaat yang dapat mempengaruhi nilai uang dengan keberadaan pengunjung restoran yang membawakan karya cipta lagu milik orang lain, maka pihak restoran wajib sebelumnya mendapatkan izin secara tertulis dari pihak pencipta. Pihak restoran juga dapat melakukan pembayaran imbalan berupa royalti yang wajar kepada pencipta lagu melalui lembaga manajemen kolektif. Pembayaran imbalan dilakukan pihak restoran melalui lembaga manajemen kolektif tempat pencipta terdaftar sebagai anggotanya. Pihak restoran yang mendapatkan manfaat ekonomi namun tidak mendapatkan izin dari pencipta atau tidak melakukan kewajiban berupa pembayaran royalti dapat dimintakan pembayaran sejumlah uang melalui putusan pengadilan yang berkekuatan hukum tetap karena telah melanggar hak ekonomi pencipta lagu.

III.

\section{PENUTUP}

\subsection{Simpulan}

Keberadaan pengunjung restoran yang menyanyikan lagu secara volunteer (suka rela) dapat dikategorikan penggunaan secara komersial oleh pihak restoran dalam hal secara nyata mendapatkan manfaat ekonomi atau mendapatkan manfaat yang dapat mempengaruhi nilai uang dengan keberadaan pengunjung restoran yang membawakan karya cipta lagu milik orang lain. Pihak restoran wajib mendapatkan izin secara tertulis dari pihak pencipta atau melakukan pembayaran imbalan berupa royalti 
yang wajar kepada pencipta lagu melalui lembaga manajemen kolektif.

\section{DAFTAR PUSTAKA}

\section{Buku:}

Dharmawan, Ni Ketut Supasti, dkk., 2017, Buku Ajar Hak Kekayaan Intelektual (HKI), Deepublish, Yogyakarta

Hidayah, Khoirul, 2017, Hukum Hak Kekayaan Intelektual, Setara Press, Jawa Timur

HS, Salim, 2002, Pengantar Hukum Perdata Tertulis (BW), Sinar Grafika, Jakarta

Jamalus, 1988, Pengajaran Musik Melalui Pengalaman Musik, Departemen Pendidikan Dan Kebudayaan, Jakarta

Muhammad, Abdulkadir, 2014, Hukum Perdata Indonesia, PT Citra Aditya Bakti, Bandung

Saidin, OK, 2015, Aspek Hukum Hak Kekayaan Intelektual (Intellectual Property Rights), Cetakan ke-9, PT Raja Grafindo Persada, Jakarta

Soelistyo, Henry, 2011, Hak Cipta Tanpa Hak Moral, Rajawali Pers, Jakarta

Tutik, Titik Triwulan, 2011, Hukum Perdata Dalam Sistem Hukum Nasional, Cetakan ke-3, Kencana, Jakarta

Jurnal Ilmiah:

Dharmawan, Ni Ketut Supasti, 2017, Protecting Traditional Balinese Weaving Trough Copyright Law : Is It Appropriate? : Jurnal Diponegoro Law Review Vol. 02 Nomor 01, Universitas Diponegoro

Syamsudin, M., 2001, Nilai-Nilai Karya Cipta Dan Problematik Perlindungan Hukumnya: Jurnal Hukum Ius Quia Iustum Vol. 8 Nomor 16, Universitas Islam Indonesia 